\title{
Germination Under Alkaline Conditions and Transmission of Alkali Resistance by Endospores of Certain Strains of Bacillus cereus and Bacillus circulans
}

\author{
By MARGARET E. CHISLETT* \\ Microbiology Department, University of Reading, England \\ AND D. J. KUSHNER \\ Forest Insect Laboratory, Sault Ste. Marie, Ontario, Canada
}

(Received 28 November 1960)

\section{SUMMARY}

Endospores of Bacillus cereus Frankland and Frankland strain $\mathbf{R}$ (which is able to grow under highly alkaline conditions) germinated at a higher $\mathrm{pH}$ value than spores of an alkali-sensitive strain, Mu-3055. Spores of $B$. circulans Jordan strain Ru 38 (able to grow at $\mathrm{pH} 11 \cdot 0$ ) germinated at $\mathrm{pH}$ 11.0. Spore germination at any $\mathrm{pH}$ value was generally followed by outgrowth to the vegetative rod. Outgrowth of germinated spores of $B$. cereus $\mathrm{R}$ at $\mathrm{pH} 10.0$ and of those of $B$. circulans $\mathrm{Ru} 38$ at $\mathrm{pH} 11.0$ took place at $30^{\circ}$ but not at $37^{\circ}$. Growth from a vegetative inoculum of $B$. cereus $\mathrm{R}$ at $\mathrm{pH} 10.0$ or 10.3 took place more readily at $30^{\circ}$ than at $37^{\circ}$. The ability of the vegetative forms of both bacterial species to grow under alkaline conditions was transmitted through the endospore.

\section{INTRODUCTION}

Two strains of alkali-resistant Bacillus species have recently been described: a strain of $B$. cereus Frankland and Frankland able to grow in media of $\mathrm{pH} \mathrm{10.3}$ (Kushner \& Lisson, 1959), and a strain of $B$. circulans Jordan able to grow at pH 11.0 (Chislett \& Kushner, 1961). Previous work was largely concerned with the effect of alkaline media on the vegetative growth of these organisms, but gave no information about the effect of such alkaline media on endospore germination. We have now examined the effect of alkaline conditions on the development of the vegetative form from the endospore and have examined how the ability of the vegetative form to grow under alkaline conditions is transmitted through the endospore.

\section{METHODS}

Organisms. Bacillus cereus strain Mu-3055 (non-adapted: sensitive to alkali) and $B$. cereus strain $\mathrm{R}$ (adapted from $\mathrm{Mu}-3055$ and resistant to alkali); both described by Kushner \& Lisson (1959); B. circulans strain $\mathrm{Ru} 38$ (maintained routinely on buffered nutrient agar ( $\mathrm{pH} 7 \cdot 4$ ) but capable of growth at $\mathrm{pH} 11 \cdot 0$ ); described by Chislett \& Kushner (1961).

* Present address: Division of Applied Biology, Microbiology Section, National Research Council, Ottawa 2, Canada. 
Culture media. The media used were: phosphate-buffered nutrient broth (BNB) and phosphate-buffered nutrient agar (BNA) of final $\mathrm{pH}$ values $\boldsymbol{7 \cdot 4}$ and higher, prepared as before (Kushner \& Lisson, 1959; Chislett \& Kushner, 1961).

Preparation of spore suspensions. The three strains were subcultured several times in $\mathrm{BNB}$ ( $\mathrm{pH} 7 \cdot 4$ ), with incubation at $30^{\circ}$, before finally spreading $1 \mathrm{ml}$. of $6 \mathrm{hr}$. culture on the surface of $50 \mathrm{ml}$. BNA ( $\mathrm{pH} 7 \cdot 4$ ) in a $20 \mathrm{oz}$. bottle; $\mathrm{MnSO}_{4} \cdot \mathbf{4 H}_{2} \mathrm{O}$ had been added to the BNA medium to a final concentration of 5 p.p.m. $\mathrm{Mn}^{++}$, and additional agar (Davis, New Zealand) was added to give a final concentration of $3 \%(\mathrm{w} / \mathrm{v})$ agar in the medium. The Bacillus cereus strains were incubated at $30^{\circ}$ for $\boldsymbol{7}$ days and the $\boldsymbol{B}$. circulans strain for 14 days. Spores were harvested by washing off the growth with sterile distilled water and glass beads. The resulting suspension was washed six times in sterile distilled water at $5^{\circ}$ and the deposit, consisting almost

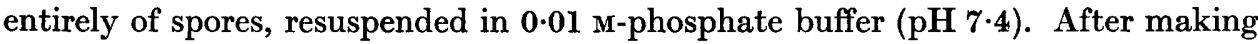
viable spore counts on nutrient agar plates, the spore suspensions were diluted with 0.01 M-phosphate buffer ( $\mathrm{pH} \mathrm{7 \cdot 4}$ ) to contain $10^{9}$ viable spores $/ \mathrm{ml}$. and held at $5^{\circ}$ until required. Before making viable counts and before use in the experiments described in Table 1 , the portion of each spore suspension used was heated at $80^{\circ}$ for 15 min., then cooled rapidly in an ice bath and held at $5^{\circ}$ until required. In the experiments shown in Table 2 and in those with shaken cultures of $B$. circulans, the spores used had been prepared in a similar manner, with the following variations in technique: BNA medium (pH 7.4) with 5 p.p.m. $\mathrm{Mn}^{++}$added was used; incubation was for 7 days at $37^{\circ}$ instead of at $30^{\circ}$. At the end of this time there was a high degree of sporulation and comparatively few vegetative forms remained. The washed suspensions of spores + bacteria were heated for $1 \mathrm{hr}$. at $60^{\circ}$, adjusted to a concentration of $3 \times 10^{8}$ viable spores $/ \mathrm{ml}$. and stored in distilled water at $5^{\circ}$.

Germination of spores at $\mathrm{pH} 7 \cdot 4$ and at alkaline $\mathrm{pH}$ values. Spore suspensions were added to $10 \mathrm{ml}$. BNB medium in 6 in. $\times \frac{5}{8}$ in. tubes at $\mathrm{pH}$ values from $7 \cdot 4$ to $11 \cdot 0$, to give a final concentration of $10^{7}$ viable spores $/ \mathrm{ml}$. Incubation was at $30^{\circ}$ and $37^{\circ}$, and examinations were made at $2,4,6,8,10,12$ and $24 \mathrm{hr}$. Spore germination was detected by examining the suspension in a haemocytometer, by using a $4 \mathrm{~mm}$. phase contrast objective (see Berger \& Marr, 1960). Under phase contrast, the ungerminated spores appeared refringent, thus allowing a direct spore count. The staining method of Conklin (1934) with malachite green and mercurochrome, whereby ungerminated spores stained green and germinated spores and vegetative forms red, gave a good correlation with the results obtained by the haemocytometer and phase contrast method. For quantitative determinations of the number of germinated and ungerminated spores $/ \mathrm{ml}$., and to estimate percentage germination, $0.01 \mathrm{ml}$. spore suspension was delivered by a dropping pipette on to a marked area of $1 \mathrm{~cm} .{ }^{2}$ on a slide and the suspension stained by Conklin's method. As soon as microscopic observation showed that the spores were germinating, the $\mathrm{pH}$ values of the cultures and of control tubes of uninoculated media were measured. The results have been recorded as the relative extent of germination at the earliest time this process was observed (see Table 1). Once germination of even a small proportion of spores had taken place, subsequent vegetative cell growth lowered the $\mathrm{pH}$ value of the medium (Kushner \& Lisson, 1959; Chislett \& Kushner, 1961). For this reason, information about the time-course of germination of a spore population at a given $\mathrm{pH}$ value could not readily be obtained in these experiments. 
Outgrowth. The successive changes leading to the formation of a vegetative rod from a germinated spore have been termed 'outgrowth' (Campbell, 1957). This process has been recorded here qualitatively simply by noting the first appearance of vegetative rods in the culture medium.

Transmission of alkali resistance. Growing cultures in BNB medium (pH 7·4) resulting from spore germination at this $\mathrm{pH}$ value were inoculated into duplicate tubes of $\mathrm{BNB}$ medium at different $\mathrm{pH}$ values between $7 \cdot 4$ and 11.0 . The inocula were two $4 \mathrm{~mm}$. loopfuls of an 18-21 hr. culture at $37^{\circ}$. The tubes were incubated at $30^{\circ}$ or $37^{\circ}$ and examined at intervals. As soon as growth was visible as turbidity the cultures were examined microscopically, and $\mathrm{pH}$ measurements were made of the cultures and of control tubes of uninoculated media.

\section{RESULTS}

Spore germination and outgrowth

At $\mathrm{pH} \mathbf{7 \cdot 4}$, both alkali-sensitive and alkali-resistant strains of Bacillus cereus showed considerable germination and outgrowth after $2 \mathrm{hr}$. at $30^{\circ}$ or $37^{\circ}$ (Table 1 ). At $\mathrm{pH} \mathrm{9.5,} \mathrm{spore} \mathrm{germination} \mathrm{and} \mathrm{outgrowth} \mathrm{took} \mathrm{place} \mathrm{much} \mathrm{more} \mathrm{rapidly} \mathrm{and}$ extensively with the alkali-resistant strain than in the alkali-sensitive strain. Both processes were seen at $\mathrm{pH} 10 \cdot 0$ with $B$. cereus $\mathrm{R}$, but not with $B$. cereus $\mathrm{Mu}-3055$. Germination did not take place at $\mathrm{pH}$ values higher than 10.0 with either strain. At the highest $\mathrm{pH}$ values at which germination was possible for each strain, this process and/or outgrowth took place more slowly, if at all, at $37^{\circ}$ than at $30^{\circ}$.

Table 1. Germination and outgrowth of spores of alkali-sensitive and alkali-resistant Bacillus cereus and of alkali-resistant $\mathbf{B}$. circulans

\section{Organism}

B. cereus $\mathrm{Mu} 3055$

(alkali-sensitive)

B. cereus $\mathbf{R}$

(alkali-resistant)

B. circulans Ru 38
(alkali-resistant)

(alkali-resistant)

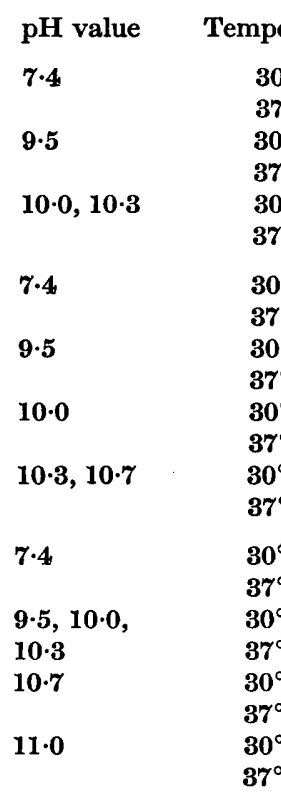

$$
\begin{aligned}
& \text { Outgrowth } \\
& + \text { at } 2 \mathrm{hr} . \\
& + \text { at } 2 \mathrm{hr} . \\
& + \text { at } 4 \mathrm{hr} . \\
& + \text { at } 24 \mathrm{hr} . \\
& \text { - at } 24 \mathrm{hr} . \\
& \text { - at } 24 \mathrm{hr} . \\
& + \text { at } 2 \mathrm{hr} . \\
& + \text { at } 2 \mathrm{hr} . \\
& + \text { at } 4 \mathrm{hr} . \\
& + \text { at } 4 \mathrm{hr} . \\
& + \text { at } 24 \mathrm{hr} . \\
& \text { - at } 24 \mathrm{hr} . \\
& \text { - at } 24 \mathrm{hr} . \\
& \text { - at } 24 \mathrm{hr} . \\
& + \text { at } 4 \mathrm{hr} . \\
& + \text { at } 4 \mathrm{hr} . \\
& + \text { at } 2 \mathrm{hr} . \\
& + \text { at } 2 \mathrm{hr} . \\
& + \text { at } 4 \mathrm{hr} . \\
& + \text { at } 4 \mathrm{hr} . \\
& + \text { at } 4 \mathrm{hr} . \\
& \text { + at } 24 \mathrm{hr} .
\end{aligned}
$$

* \% spores germinated reported as follows : $(+) \mathbf{5} \%,+\mathbf{5 - 2 0} \%,++\mathbf{2 0 - 5 0} \%,+++>\mathbf{5 0} \%$. $\uparrow$ Outgrowth $=$ appearance of rods at time indicated. 
The results obtained with spores of the alkali-resistant Bacillus circulans strain Ru 38 differed markedly from those obtained with the $B$. cereus strains in that germination was more extensive after $2 \mathrm{hr}$. at $\mathrm{pH}$ values from $9 \cdot 5$ to $10 \cdot 3$ than at $\mathrm{pH} \mathrm{7 \cdot 4}$. Outgrowth was observed within $2 \mathrm{hr}$. with the $\mathrm{pH}$ range $9 \cdot 5-10 \cdot 3$, but was not observed until $4 \mathrm{hr}$. at $\mathrm{pH} \mathrm{7.4}$. Results at $\mathrm{pH} 10.7$ or 11.0 were similar to those found at $\mathrm{pH} 7 \cdot 4$, except that at $\mathrm{pH} 11 \cdot 0$, outgrowth took place at $30^{\circ}$ but not at $37^{\circ}$.

\section{Transmission of alkali resistance}

Following spore germination at $\mathrm{pH} 7 \cdot 4$, the vegetative form of Bacillus cereus

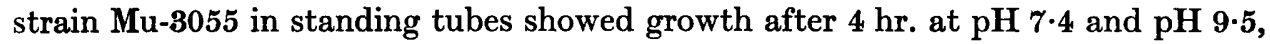
at $30^{\circ}$ and at $37^{\circ}$; no growth occurred at $\mathrm{pH} 10.0$ or higher. B. cereus strain $\mathrm{R}$ showed growth after $4 \mathrm{hr}$. at $\mathrm{pH} \mathrm{7.4}$ and $\mathrm{pH} \mathrm{9.5}$, at $30^{\circ}$ and at $37^{\circ}$. At $\mathrm{pH} 10 \cdot 0$ and $\mathrm{pH} 10 \cdot 3$, growth was observed within $12 \mathrm{hr}$. at $30^{\circ}$, but not until $24 \mathrm{hr}$. at $37^{\circ}$. $B$. circulans strain $\mathrm{Ru} 38$ showed growth after $4 \mathrm{hr}$. at $37^{\circ}$ in the $\mathrm{pH}$ range $7 \cdot 4$ to $11 \cdot 0$, but at $30^{\circ}$ growth was not observed in this $\mathrm{pH}$ range until after $6 \mathrm{hr}$. incubation.

\section{Table 2. Effect of $\mathrm{pH}$ value on the growth of alkali-sensitive and alkali-resistant Bacillus cereus following spore germination at $\mathrm{pH} 7 \cdot 4$}

In Expts. 2 and 3 one drop of spore suspension of strain Mu-3055 or strain $R$ was added to $10 \mathrm{ml}$. BNB (pH 7.4) medium and incubated $4 \mathrm{hr}$. with shaking at $37^{\circ}$, to an optical density of $0.7-0.8$. Three drops of each culture were added to tubes of BNB medium of different $\mathrm{pH}$ values. Shaking and measurements of optical density were as described by Kushner \& Lisson (1959).

Data for Expt. 1 from Table 3 of Kushner \& Lisson (1959).

\begin{tabular}{|c|c|c|c|c|}
\hline \multirow{2}{*}{$\begin{array}{c}\text { Expt. } \\
1\end{array}$} & \multirow{2}{*}{$\begin{array}{l}\text { Inoculum } \\
\text { Bacteria maintained on plates (mixture } \\
\text { of spores and vegetative forms) }\end{array}$} & $\begin{array}{l}\text { pH value } \\
\begin{array}{l}9 \cdot 5 \\
9 \cdot 8\end{array}\end{array}$ & \multicolumn{2}{|c|}{$\begin{array}{lr}\begin{array}{l}\text { Sensitive } \\
\text { (strain }\end{array} & \text { Resistant } \\
\text { Mu-3055) } & \text { (strain R) } \\
T_{0.4} & (\mathrm{hr} .)^{*}\end{array}$} \\
\hline & & $\begin{array}{r}9 \cdot 5 \\
9 \cdot 8 \\
10 \cdot 0 \\
10 \cdot 1\end{array}$ & $\begin{aligned} & 16 \\
> & 25 \\
> & 25 \\
> & 25\end{aligned}$ & $\begin{aligned} 7 \cdot 2 \\
11 \cdot 0 \\
\\
24 \cdot 8 \\
>25\end{aligned}$ \\
\hline 2 & $\begin{array}{l}\text { Bacteria obtained by spore germination, } \\
2 \text { weeks after preparation of spores }\end{array}$ & $\begin{array}{l}9 \cdot 4 \\
9 \cdot 8 \\
9 \cdot 9\end{array}$ & $\begin{array}{r}9 \\
>24 \\
>24\end{array}$ & $\begin{array}{r}5 \\
10 \\
20\end{array}$ \\
\hline $\mathbf{3}$ & $\begin{array}{l}\text { Bacteria obtained by spore germination, } \\
16 \text { weeks after preparation of spores }\end{array}$ & $\begin{array}{l}9 \cdot 4 \\
9 \cdot 8 \\
9 \cdot 9\end{array}$ & $\begin{array}{r}10 \\
>24 \\
>24\end{array}$ & $\begin{array}{r}4 \\
21 \\
>24\end{array}$ \\
\hline
\end{tabular}

* Time at which cultures reached a (net) optical density of $0 \cdot 4$.

An examination of the effects of $\mathrm{pH}$ value on the vegetative growth of Bacillus cereus derived from spores was also made in shaken cultures at $37^{\circ}$ (Table 2). Once growth had begun there was, as before noted (Kushner \& Lisson, 1959), little effect of the initial $\mathrm{pH}$ value on the growth rate; and the growth rates observed were similar to those reported by Kushner \& Lisson (1959). Thus vegetative forms derived from spores 2 weeks after sporulation had retained full alkali resistance. After an additional 14 weeks storage of the spores in distilled water at $5^{\circ}$, however, there was some loss of alkali resistance; the vegetative forms from germinated spores were no longer able to grow at $\mathrm{pH} 9.9 \mathrm{in} 24 \mathrm{hr}$. 
In an experiment with spores of the alkali-resistant Bacillus circulans, an inoculum of the vegetative form was prepared by incubating these spores overnight on a BNA medium plate $(\mathrm{pH} \mathrm{7.4)}$ ), and a series of tubes containing BNB medium of different $\mathrm{pH}$ values was inoculated and shaken as before (Chislett \& Kushner, 1961). The growth curves obtained were virtually identical with those given by the alkaliresistant $B$. circulans which had been maintained at $\mathrm{pH} \mathbf{7 \cdot 4}$ and transferred as a mixture of spores and vegetative forms (Chislett \& Kushner, 1961, Fig. 1a).

These results indicated that growth of the alkali-resistant bacteria took place at a slightly higher $\mathrm{pH}$ value in standing than in shaken cultures. However, in standing cultures at $30^{\circ}$ and $37^{\circ}$ Bacillus cereus $\mathrm{R}$ showed growth at $\mathrm{pH} 10 \cdot 3$ (as above) but not at $\mathrm{pH} 10.7$; and $B$. circulans $\mathrm{Ru} 38$ showed growth at $\mathrm{pH} 11.0$ (as above) but not at $\mathrm{pH} 12 \cdot 0$. The highest $\mathrm{pH}$ value at which growth was observed for $B$. circulans $\mathrm{Ru} 38$ was $\mathrm{pH} 11 \cdot 4$ ( $\mathrm{pH}$ value of standing culture) after $18 \mathrm{hr}$. at $37^{\circ}$.

\section{DISCUSSION}

In obtaining Bacillus cereus strain $\mathbf{R}$ the culture method used was designed to select vegetative forms with ability to grow at higher $\mathrm{pH}$ values than could the original culture, rather than to select spores that could germinate at higher $\mathrm{pH}$ values (Kushner \& Lisson, 1959). It was conceivable that such alkali-resistant vegetative forms might produce spores whose germination was as sensitive to highly alkaline conditions as were spores of the original alkali-sensitive cultures. It has now been found that spores of this selected alkali-resistant strain can germinate and develop into vegetative rods at higher $\mathrm{pH}$ values than spores of the original strain Mu-3055. The upper $\mathrm{pH}$ limit for spore germination of $B$. cereus strain $\mathbf{R}$ spores is slightly lower than the upper limit for growth.

Spores of the alkali-resistant Bacillus circulans $\mathrm{Ru} 38$ can also germinate in highly alkaline media; when incubation is at $30^{\circ}$, they can germinate in a medium of the highest $\mathrm{pH}$ value at which growth is possible. Germination and outgrowth took place more rapidly at $\mathrm{pH} 9 \cdot 5-10 \cdot 3$ than at $\mathrm{pH} \mathrm{7 \cdot 4}$; and it should be noted that vegetative growth of $\boldsymbol{B}$. circulans $\mathrm{Ru} 38$ began after a shorter lag period at $\mathrm{pH} \mathbf{9 \cdot 9}$

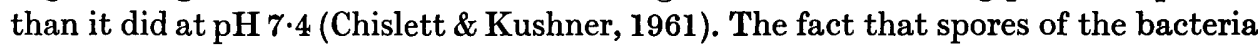
studied had the ability to develop into vegetative forms and these to multiply at high $\mathrm{pH}$ values suggests that the alkali resistance of these processes may have a common physiological basis.

In so far as it has been studied, the effect of temperature on the processes of growth and spore germination at different $\mathrm{pH}$ values seems complex. Although a temperature of $37^{\circ}$ could cause growth to take place more rapidly than a temperature of $30^{\circ}$, at the highest $\mathrm{pH}$ values at which germination and growth were possible, germination, outgrowth and vegetative growth of Bacillus cereus $\mathbf{R}$ and outgrowth of $B$. circulans $\mathrm{Ru} 38$ took place more rapidly, or only at $30^{\circ}$. Thus, despite its ability to accelerate growth, the higher temperature also increased the toxic effects of highly alkaline media.

The alkali-resistant Bacillus circulans strain Ru 38 has been deposited with the National Collection of Industrial Bacteria, Torry Research Station, Aberdeen, Scotland, and allotted the number NCIB 9218. 
We are indebted to Professor B. C. J. G. Knight for advice during this investigation. This paper is contribution No. 671, Forest Biology Division, Research Branch, Department of Agriculture, Ottawa, Canada.

\section{REFERENCES}

Berger, J. A. \& MARr, A. G. (1960). Sonic disruption of spores of Bacillus cereus. J. gen. Microbiol. 22, 147.

CAMPBeLL, L. L. (1957). Bacterial spore germination-definitions and methods of study. In Spores (H. O. Halvorson, Ed.), Amer. Inst. Biol. Sci., Wash. Publ. no. 5, 33.

Chislett, M. E. \& Kushner, D. J. (1961). A strain of Bacillus circulans capable of growing under highly alkaline conditions. J. gen. Microbiol. 24, 187.

Conkirn, M. E. (1934). Mercurochrome as a bacteriological stain. J. Bact. 27, 30.

Kushner, D. J. \& Lisson, T. A. (1959). Alkali resistance in a strain of Bacillus cereus pathogenic for the larch sawfly Pristiphora erichsonii. J. gen. Microbiol. 21, 96. 